\title{
Latissimus dorsi detrusor myoplasty for bladder acontractility: a systematic review
}

\author{
Antonio Jorge Forte ${ }^{1}$, Daniel Boczar ${ }^{1}$, Maria Tereza Huayllani ${ }^{1}$, Steven Moran $^{2}$, \\ Oluwaferanmi O. Okanlami ${ }^{3}$, Milomir Ninkovic ${ }^{4}$, Peter N. Broer ${ }^{4}$ \\ ${ }^{1}$ Division of Plastic Surgery, Mayo Clinic, Jacksonville, FL; ${ }^{2}$ Division of Plastic Surgery, Mayo Clinic, Rochester, MN; ${ }^{3}$ Departments of Family \\ Medicine and Physical Medicine \& Rehabilitation, University of Michigan, Ann Arbor, MI, USA; ${ }^{4}$ Department of Plastic, Reconstructive, \\ Hand and Burn Surgery, Bogenhausen Academic Hospital, Munich, Germany
}

\begin{abstract}
Bladder acontractility affects several thousand patients in the United States, but the available therapies are limited. Latissimus dorsi detrusor myoplasty (LDDM) is a therapeutic option that allows patients with bladder acontractility to void voluntarily. Our goal was to conduct a systematic review of the literature to determine whether LDDM is a better option than clean intermittent catheterization (CIC) (standard treatment) in patients with bladder acontractility. On January 17, 2020, we conducted a systematic review of the PubMed/MEDLINE, Cochrane Clinical Answers, Cochrane Central Register of Controlled Trials, Embase, and ClinicalTrials.gov databases, without time frame limitations, to identify articles on the use of LDDM for bladder acontractility. Of 75 potential articles, 4 fulfilled the eligibility criteria. The use of LDDM to treat patients with bladder acontractility was reported in four case series by the same group in Europe. Fifty-eight patients were included, and no comparison groups were included. The most common cause of bladder acontractility was spinal cord injury $(n=36)$. The mean ( \pm standard deviation) operative time was $536( \pm 22)$ minutes, postoperative length of hospital stay ranged from 10 to 13 days, and follow-up ranged from 9 to 68 months. Most patients had complete response, were able to void voluntarily, and had post-void residual volume less than $100 \mathrm{~mL}$. Although promising outcomes have been obtained, evidence is still weak regarding whether LDDM is better than CIC to avoid impairment of the urinary tract among patients with bladder acontractility. Further prospective studies with control groups are necessary.
\end{abstract}

Keywords Urinary bladder, neurogenic / Free tissue flaps / Superficial back muscles
Correspondence: Antonio Jorge Forte Division of Plastic Surgery, Mayo Clinic, 4500 San Pablo Rd, Jacksonville, FL 32224, USA Tel: +1-904-953-2073 Fax: +1-904-953-7368 E-mail: ajvforte@yahoo.com.br

Received: March 5, 2021 • Revised: April 29, $2021 \bullet$ Accepted: May 27, 2021

pISSN: 2234-6163 • elSSN: 2234-6171 • https://doi.org/10.5999/aps.2021.00402 • Arch Plast Surg 2021;48:528-533

\section{INTRODUCTION}

Bladder acontractility is an irreversible condition that leads to urinary tract impairment. In the United States, several thousand patients with lower motor neuron lesion are estimated to have bladder acontractility [1]. However, few therapies are currently available, and patients need to perform catheterization multiple times per day. If left untreated, bladder acontractility typically promotes urinary retention, leading to urinary tract infection, vesicoureteral reflux, and stone formation [2].

Bladder acontractility is a prevalent condition that has multiple causes. Satisfactory bladder emptying results from coordinated

Copyright $\odot 2021$ The Korean Society of Plastic and Reconstructive Surgeons

This is an Open Access article distributed under the terms of the Creative Commons Attribution Non-Commercial License (https://creativecommons.org/

licenses/by-nc/4.0/) which permits unrestricted non-commercial use, distribution, and reproduction in any medium, provided the original work is properly cited. I www.e-aps.org 
bladder contraction and ureteral relaxation [3]. Therefore, its pathophysiologic factors may be damage at the spinal micturition center, the innervation of the detrusor muscle, or the detrusor muscle itself [2]. Examples of associated conditions are spinal cord injury, cerebral stroke, Parkinson disease, multiple sclerosis, and congenital anomalies such as myelomeningocele [4-6].

Currently, therapies that allow patients with bladder acontractility to void are limited, and the standard therapy is clean intermittent catheterization (CIC) [2,3]. Although CIC reduces urinary disease-related death, it is also correlated to important adverse effects $[7,8]$. CIC also has risks of urethral laceration, bladder perforation, deterioration of bladder function, and recurrent urinary tract infection [1]. Moreover, as a lifelong treatment, CIC also brings an important psychological and socioeconomic burden [1].

The latissimus dorsi flap is a well-established and versatile flap for reconstructive surgery. The latissimus dorsi muscle (LDM) is innervated by the thoracodorsal nerve, has a long pedicle, and has the advantage of being a wide muscle [3]. Experimental studies in the canine model have shown the feasibility of transferring the LDM to the urinary bladder for use as a reinnervated functional muscle flap in detrusor myoplasty $[9,10]$. An article published in 1998 reported the first use of latissimus dorsi detrusor myoplasty (LDDM) to treat three patients with bladder acontractility. These patients were able to void voluntarily a few months after the procedure [11]. Therefore, we conducted a systematic review of the literature on the use of latissimus dorsi free flap for bladder acontractility. Our aim was to determine whether LDDM is better than CIC to avoid urinary tract impairment in patients with bladder acontractility.

\section{MATERIALS AND METHODS}

\section{Search strategy}

This study followed the guidelines outlined in the Preferred Reporting Items for Systematic Reviews and Meta-Analyses (PRISMA). On January 17, 2020, two authors (DB and MTH) conducted independent searches of the PubMed/MEDLINE, Cochrane Clinical Answers, Cochrane Central Register of Controlled Trials, Embase, and ClinicalTrials.gov databases, without time frame limitations. The search was performed with the following keywords: ("bladder" OR "urinary bladder" OR "detrusor") AND ("myoplasty" OR "muscle free flap" OR "innervated free skeletal muscle" OR "free innervated muscle flap").

The title and abstract were initially screened, and then the full text was reviewed. Duplicate articles were excluded, and disagreements regarding article identification and final selection for inclusion were resolved by another author (AJF). We also examined the reference lists of the studies that fulfilled the study eligibility criteria (see the Selection criteria section below), and we looked for articles not identified with our initial search.

\section{Selection criteria}

We included studies that reported data about the use of innervated latissimus dorsi free flap for bladder acontractility. We did not restrict the time frame. We excluded studies that investigated other treatments of bladder atony, such as detrusor remodeling and electrical stimulation. We also excluded articles that focused on other muscles such as the rectus abdominis. Reviews, meta-analyses, correspondences, non-English articles, and experimental studies were also excluded.

\section{Data extraction and processing}

We extracted data about year of publication, country, study design, level of evidence, patient characteristics, cause of bladder acontractility, preoperative evaluation, operative time, length of hospital stay, postoperative evaluation, follow-up, outcomes, and complications. Two authors (DB and MTH) extracted data from the text, tables, and figures, and another author (AJF) confirmed the accuracy of data entry.

\section{RESULTS}

\section{Study characteristics}

Of 75 articles identified with the search, four fulfilled the eligibility criteria (Table 1, Fig. 1). The use of LDDM to restore voiding was reported in four case series by the same group from Europe. The first study was published in 1998 and the most recent in 2011. In total, 58 patients with bladder acontractility were evaluated. The most common cause was spinal cord injury $(n=36)$, followed by congenital malformation $(n=6)$, idiopathy $(n=9)$, and chronic overdistension of the bladder $(n=5)$. All studies used a similar surgical technique. The mean \pm standard deviation operative time was $536 \pm 22$ minutes [12], postoperative length of stay in the hospital ranged from 10 to 13 days, and follow-up ranged from 9 to 68 months $[12,13]$. Patients performed CIC for 2 to 3 months after surgery and then were asked to start voiding spontaneously. Different examinations were applied to evaluate therapy response. Voluntary voiding, reduced post-void residual volume, reduced frequency of CIC, or a combination of these outcomes were reported for most patients.

In 1998, Stenzl et al. [11] published a case series of three patients with bladder acontractility who were treated with LDDM and required regular $\mathrm{CIC}$ for more than 2 years. Within 16 to 30 weeks after the procedure, all patients were able to voluntarily void. Postoperative assessment was done with urodynamic eval- 
Table 1. Summary of the studies

\begin{tabular}{|c|c|c|c|c|}
\hline Variable & & & Study & \\
\hline Author & Stenzl et al. [11] & Stenzl and Ninkovic [14] & Ninkovic et al. [12] & Gakis et al. [13] \\
\hline Year & 1998 & 2001 & 2003 & 2011 \\
\hline Country & Austria & Austria & Austria & Germany \\
\hline Study type & Case series & Case series & Case series & Case series \\
\hline Level of evidence & IV & IV & IV & IV \\
\hline No. of patients & 3 & 11 & 20 & 24 \\
\hline Sex, M/F & - & $7 / 4$ & $14 / 6$ & $16 / 8$ \\
\hline Age (yr), mean (range) & $40.6(23-68)$ & $42(9-68)$ & $39.4(9-68)$ & 39 (13-63) \\
\hline Etiology (n) & $\begin{array}{l}\text { Spinal cord injury (2); chronic } \\
\text { overdistension (1) }\end{array}$ & $\begin{array}{l}\text { Traumatic spinal cord injury (6); congenital } \\
\text { malformation (2); idiopathic (1); } \\
\text { chronically overdistended bladder (1) }\end{array}$ & $\begin{array}{l}\text { I Spinal cord injury (12); idiopathic } \\
\text { (5); congenital (3) }\end{array}$ & $\begin{array}{l}\text { Spinal cord injury (16); congenital } \\
\text { malformation (1); idiopathic (4); } \\
\text { chronically overdistended bladder (3) }\end{array}$ \\
\hline Preoperative evaluation & - & - & $\begin{array}{l}\text { Urodynamic assessment, } \\
\text { cystoscopy, upper tract imaging } \\
\text { and electro-myography of the } \\
\text { rectus muscle }\end{array}$ & $\begin{array}{l}\text { Video urodynamics, diagnostic urethra } \\
\text { cystoscopy and excretory urography. In } \\
\text { addition, electromyography of the lower } \\
\text { portion of the rectus abdominis muscle }\end{array}$ \\
\hline $\begin{array}{l}\text { Operation time (min), } \\
\text { mean } \pm S D\end{array}$ & - & - & - & $536 \pm 22$ \\
\hline $\begin{array}{l}\text { Length of hospital stay } \\
\text { (day), mean (range) }\end{array}$ & - & - & $10(8-14)$ & $13(7-32)$ \\
\hline $\begin{array}{l}\text { Postoperative } \\
\text { evaluation }\end{array}$ & $\begin{array}{l}3 \text { Months: uroflow, } \\
\text { assessment of voided } \\
\text { volume and residual urine, } \\
\text { intravenous urography, and } \\
\text { Doppler sonography of the } \\
\text { bladder; } 6 \text { and } 12 \text { months: } \\
\text { urodynamic evaluation and } \\
\text { flow-mode CT }\end{array}$ & $\begin{array}{l}3 \text { Months: measurements of uroflow, } \\
\text { urine voiding volumes, urine, and } \\
\text { residual, intravenous urography, and } \\
\text { Doppler sonography of the bladder; } \\
6 \text { and } 12 \text { months: urodynamic } \\
\text { evaluation and flow-mode CT }\end{array}$ & $\begin{array}{l}3 \text { Months: Doppler } \\
\text { ultrasonography; } 6 \text { months: } \\
\text { Doppler ultrasonography; } \\
\text { dynamic computerized } \\
\text { tomography; } 12 \text { months: } \\
\text { Doppler ultrasonography; } \\
\text { dynamic computerized } \\
\text { tomography; excretory } \\
\text { urography or ultrasonography; } \\
\text { video urodynamic evaluation }\end{array}$ & $\begin{array}{l}3 \text { Months intervals for the first year: } \\
\text { Doppler ultrasonography; } 6 \text { and } 12 \\
\text { months: video urodynamic evaluations. } \\
\text { Urodynamics and measurement of post- } \\
\text { void residual urine volume. Bladder } \\
\text { contractility index was calculated. } \\
\text { Measurement of post-void residual } \\
\text { volume and Qmax in combination with } \\
\text { urodynamics and upper urinary tract } \\
\text { imaging. Self-evaluate satisfaction with } \\
\text { postoperative outcome }\end{array}$ \\
\hline $\begin{array}{l}\text { Follow-up (mo), mean } \\
\text { (range) }\end{array}$ & $16(12-20)$ & $25(12-46)$ & $44(18-74)$ & $46(8-89)$ \\
\hline $\begin{array}{l}\text { Postoperative care (flap } \\
\text { monitoring etc) }\end{array}$ & $\begin{array}{l}\text { Permanent indwelling } \\
\text { intramuscular } \mathrm{pO}_{2} \text { probe }\end{array}$ & $\begin{array}{l}\text { Permanent indwelling intramuscular } \mathrm{pO}_{2} \\
\text { probe }\end{array}$ & $\begin{array}{l}\text { Intramuscular probe measuring } \\
\text { the } \mathrm{pO}_{2}\end{array}$ & Doppler ultrasonography regularly \\
\hline $\begin{array}{l}\text { Postsurgical } \\
\text { catheterization (wk) }\end{array}$ & $\begin{array}{l}16 \text { (2 patients); } 30 \\
\text { (1 patient) }\end{array}$ & $8-12$ & $8-12$ & 12 \\
\hline Measure of follow-up & $\begin{array}{l}\text { Voluntary voiding; Post-void } \\
\text { residual volume }\end{array}$ & $\begin{array}{l}\text { Voluntary voiding; Reduction in CIC; } \\
\text { Post-void residual volume }\end{array}$ & $\begin{array}{l}\text { Voluntary voiding; Post-void } \\
\text { residual volume; Reduction in } \\
\text { CIC }\end{array}$ & $\begin{array}{l}\text { Voluntary voiding; Bladder contractility } \\
\text { index; Post-void residual volume; } \\
\text { Reduction in CIC }\end{array}$ \\
\hline $\begin{array}{l}\text { Clinical outcomes } \\
\text { (complete/partial/no } \\
\text { response) }\end{array}$ & $\begin{array}{l}\text { - Complete response in all } \\
\text { patients (able to void } \\
\text { spontaneously with post- } \\
\text { void residual volumes of } \\
\text { less than } 100 \text { mL). Image: } \\
\text { Cystourethrography: } \\
\text { slightly irregular shape of } \\
\text { the bladder, no reflux on } \\
\text { emptying, and bladder } \\
\text { evacuation almost to } \\
\text { completion. Doppler } \\
\text { sonography and flow-mode } \\
\text { CT: The well-vascularized } \\
\text { transplanted latissimus } \\
\text { dorsi and its contractions } \\
\text { during bladder emptying }\end{array}$ & $\begin{array}{l}\text { - Complete response in } 8 \text { patients (able } \\
\text { to void spontaneously with post-void } \\
\text { residual volumes of less than } 100 \mathrm{~mL} \text { ). } \\
\text { - Partial response in } 2 \text { patients } \\
\text { (catheterizes themselves less often). } \\
\text { - No response in } 1 \text { patient (continues to } \\
\text { require } 4 \text { to } 5 \text { catheterizations daily); } \\
\text { Image: Voiding cystourethrography: } \\
\text { normal or slightly irregular shaped } \\
\text { bladders, no reflux on voiding, and } \\
\text { bladder evacuation almost to completion } \\
\text { among patients with voluntary voiding. } \\
\text { Doppler sonography or flow-mode CT: } \\
\text { LDM contractions during voiding }\end{array}$ & $\begin{array}{l}\text { - Complete response in } 14 \\
\text { patients (void spontaneously } \\
\text { within } 4 \text { months postoperatively } \\
\text { with post-void residual volumes } \\
\text { of less than } 100 \mathrm{~mL} \text { ). Voluntary } \\
\text { voiding was restored by bladder } \\
\text { neck incision in } 4 \text {. } \\
\text { - No response in } 2 \text { patients (still } \\
\text { require self-catheterization) } \\
\text { Postoperative detrusor } \\
\text { pressures ranged from } 5 \text { to } 218 \\
\mathrm{~cm} . \mathrm{H}_{2} \mathrm{O} \text { (mean } 72, \text { median } 55 \text { ) }\end{array}$ & $\begin{array}{l}\text { - Complete response in } 17 \text { patients } \\
\text { (complete spontaneous voiding with a } \\
\text { mean post-void residual less than } 100 \\
\text { mL). } \\
\text { - Partial response in } 3 \text { patients } \\
\text { (frequency of CIC was reduced to } 2 \text { to } \\
4 \text { times daily with a mean post-void } \\
\text { residual urine volume of } 200 \mathrm{~mL} \text { ). } \\
\text { - No response in } 4 \text { patients. Mean } \\
\text { bladder contractility index among } \\
\text { complete response patients increased } \\
\text { from 20.1 } \pm 7.6 \text { to } 176.2 \pm 25.4 \\
(P<0.001)\end{array}$ \\
\hline $\begin{array}{l}\text { Early postoperative } \\
\text { complication (n) }\end{array}$ & Dislocated probe (1) & $\begin{array}{l}\text { Dislocated probe (2); retroperitoneal } \\
\text { hematoma (1); Seroma in the axillary } \\
\text { region (1); transient unilateral loss of } \\
\text { sensation in the upper and lower } \\
\text { extremities (1) }\end{array}$ & $\begin{array}{l}\text { Dislocated probe (2); pelvic } \\
\text { hematoma (1); transient } \\
\text { peroneal nerve palsy (1); } \\
\text { seroma at the donor site (3) }\end{array}$ & \\
\hline $\begin{array}{r}\text { Late postoperative } \\
\text { complication (n) }\end{array}$ & UTI (1) & UTI and bladder stone formation (2) & UTI (2) & UTI (21) \\
\hline
\end{tabular}

M, male; F, female; CT, computed tomography; CIC, clean intermittent catheterization; LDM, latissimus dorsi muscle; UTI, urinary tract infection. 


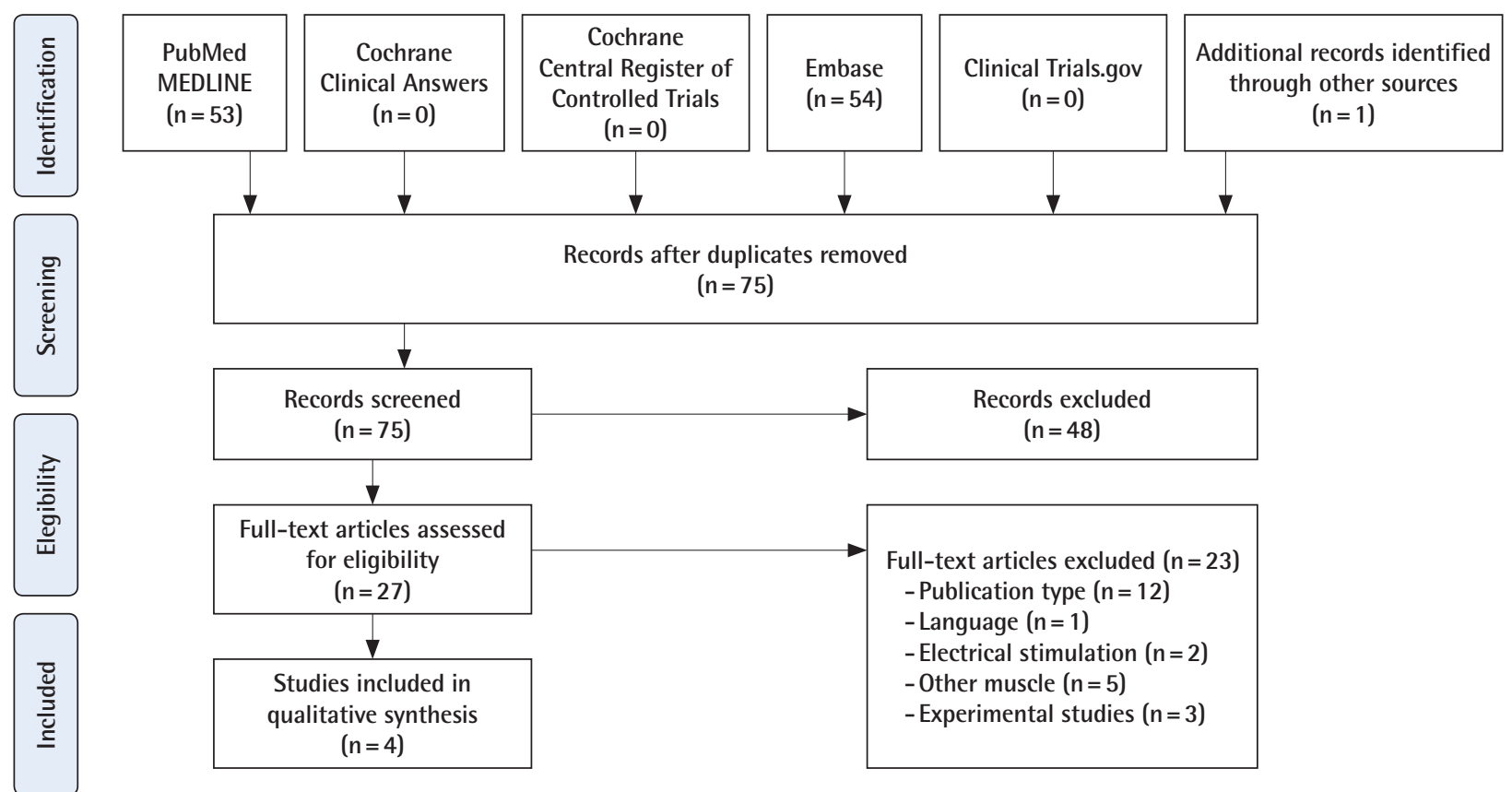

Fig. 1. Flowchart of article identification and final selection following PRISMA guidelines. Our initial search yield 54 publications. four studies were included in the final analysis. PRISMA, Preferred Reporting Items for Systematic Reviews and Meta-Analyses.

uation, color Doppler ultrasonography (USG), intravenous urography, and flow-mode computed tomography (CT). At 12 months, all patients had a complete response, with residual urinary volume less than $90 \mathrm{~mL}$. Moreover, contraction of the LDM was observed on USG and flow-mode CT [11].

Stenzl and Ninkovic [14], in 2001, published a case series of 11 patients with bladder acontractility who were treated with LDDM and needed regular CIC to void for at least 2 years. After LDDM, LDM contractions during voiding were confirmed with Doppler USG and CT. Eight patients had a complete response, defined as voluntary voiding without catheterization. Two other patients had a partial response, defined as decreased frequency of catheterization, and one patient had no response to the procedure.

In 2003, Ninkovic et al. [12] published a case series of 20 patients who required regular CIC for more than 2 years and received long-term follow-up after LDDM (mean, 44 months; range, 18-74 months). Preoperative assessments included urodynamic evaluation, upper tract imaging, cystoscopy, and electromyography of the rectus muscle; postoperative assessments included urodynamic evaluation, Doppler USG, and dynamic CT. Doppler USG and dynamic CT showed vascularization and contractility of the LDM in all patients. Four months after the procedure, 14 patients (70\%) had complete response, were able to void voluntarily, and had post-void residual volume less than $100 \mathrm{~mL}[12]$.

Gakis et al. [13] in 2011, published the long-term outcomes of a multicenter case series with 24 patients who underwent LDDM. Patients received a median follow-up of 46 months (range, 8-89 months), and post-void residual volume, urodynamics, and bladder contractility index were measured. After surgery, 17 patients (71\%) had complete response, with voluntary voiding, post-void residual volume less than $100 \mathrm{~mL}$, and significantly increased bladder contractility index (preoperative mean 20.1 vs. postoperative mean 176.2; $\mathrm{P}<0.001$ ). Among the other patients, three (15\%) had a partial response with reduced frequency of CIC, and four (20\%) had no response [13].

\section{DISCUSSION}

The scientific literature concerning the clinical use of LDDM for bladder acontractility can be summarized with four case series that included a total of 58 patients. Although two studies presented long-term follow-up data with promising results concerning voluntary voiding and absence of urinary tract deterioration, none of the four studies had a comparison group. Therefore, no sufficient data are currently available to support the use of LDDM instead of CIC to treat patients with bladder acontractility.

Several therapies have been proposed to improve bladder contractility, and these could be categorized as neurostimulation, detrusor muscle stimulation, and detrusor myoplasty. Muscle flaps other than the LDM have been used to treat patients with bladder acontractility but with limited outcomes. The rectus 
femoris and rectus abdominis are bipennate muscles, and they do not provide the sustained, adequate pressure necessary for voluntary voiding because they have shorter muscle fibers $[3,15,16]$. Use of the gracilis muscle flap has also been proposed, but the muscle does not have sufficient strength, width, or volume for use in detrusor myoplasty [17].

The case series included in this review reported promising outcomes for LDDM as a treatment of bladder acontractility. Complications among patients were mild to moderate, and no flap loss was reported. This was probably because all procedures were performed by a specialized team of plastic surgeons and urologists. Interestingly, we noted that patients with worse outcomes were older or had idiopathic bladder acontractility. Because complete response was more often found among younger patients, reasonable concerns about 10-year postsurgical outcomes remain. Currently, 89 months is the longest reported follow-up after LDDM [13].

Both LDDM and CIC have disadvantages worth noting. CIC is a lifelong treatment that causes financial and psychological burdens to patients [1]. Frequent complications include urethral laceration, bladder perforation, and recurrent urinary tract infection [1]. LDDM is a challenging surgical procedure that takes an average of 9 hours and involves two surgical teams (urology and reconstructive surgery). Patients are likely to stay hospitalized for a median of 13 days after surgery [1]. Moreover, donor site morbidity should be kept in mind, although not often mentioned in the studies. Lastly, the procedure is not successful for all patients, and approximately $30 \%$ of patients still necessitate CIC [1].

We acknowledge that this systematic review has limitations, such as the possibility of bias in the data collection from articles that fulfilled our inclusion criteria. Other reviews of the use of LDDM to treat patients with bladder acontractility were published by van Koeveringe et al. [3] and Ninkovic et al. [2]. However, our study differs from these because we conducted the first systemic search on the topic and summarized relevant data. Because one-third of the patients who underwent LDDM had partial or no response, the indications for this procedure must be considered carefully. Its cost, surgical time, and length of postoperative stay at the hospital must also be considered. We encourage prospective studies with comparison groups, long-term follow-up, and well-established preoperative criteria regarding the diagnosis and cause of bladder acontractility.

\section{CONCLUSIONS}

The scientific evidence on the use of LDDM as a treatment of bladder acontractility can be summarized in four case series with a total of 58 patients. Because none had a comparison group, whether LDDM is better than CIC (standard care) to avoid urinary tract impairment remains unknown. However, long-term follow-up showed promising results regarding patient ability to void voluntarily after the procedure.

\section{NOTES}

\section{Conflict of interest}

No potential conflict of interest relevant to this article was reported.

\section{Author contribution}

Conceptualization: AJ Forte, D Boczar, MT Huayllani, S Moran, OO Okanlami, M Ninkovic, PN Broer. Data curation: D Boczar, MT Huayllani, S Moran. Formal analysis: AJ Forte, D Boczar, OO Okanlami, PN Broer. Funding acquisition: D Boczar. Methodology: AJ Forte, D Boczar, MT Huayllani, S Moran, OO Okanlami, M Ninkovic, PN Broer. Project administration: AJ Forte, S Moran, M Ninkovic, PN Broer. Writing - original draft: AJ Forte, D Boczar, MT Huayllani. Writing - review \& editing: AJ Forte, D Boczar, S Moran, OO Okanlami, M Ninkovic, PN Broer.

\section{ORCID}

Antonio Jorge Forte https://orcid.org/0000-0003-2004-7538

Daniel Boczar https://orcid.org/0000-0002-2037-5331

Maria Tereza Huayllani

https://orcid.org/0000-0003-2690-1635

\section{REFERENCES}

1. Ginsberg DA. Bladder acontractility: detrusor myoplasty and other options. Nat Rev Urol 2011;8:185-6.

2. Ninkovic M, Stenzl A, Gakis G, et al. The latissimus dorsi detrusor myoplasty for functional treatment of bladder acontractility. Clin Plast Surg 2012;39:507-12.

3. van Koeveringe G, Rademakers K, Stenzl A. Latissimus dorsi detrusor myoplasty to restore voiding in patients with an acontractile bladder: fact or fiction? Curr Urol Rep 2013;14: 426-34.

4. de Seze M, Ruffion A, Denys P, et al. The neurogenic bladder in multiple sclerosis: review of the literature and proposal of management guidelines. Mult Scler 2007;13:915-28.

5. Sakakibara R, Uchiyama T, Yamanishi T, et al. Bladder and bowel dysfunction in Parkinson's disease. J Neural Transm (Vienna) 2008;115:443-60.

6. Tibaek S, Gard G, Klarskov P, et al. Prevalence of lower uri- 
nary tract symptoms (LUTS) in stroke patients: a cross-sectional, clinical survey. Neurourol Urodyn 2008;27:763-71.

7. Vaidyanathan S, Krishnan KR, Soni BM, et al. Unusual complications of intermittent self-catheterisation in spinal cord injury patients. Spinal Cord 1996;34:745-7.

8. Wyndaele JJ. Complications of intermittent catheterization: their prevention and treatment. Spinal Cord 2002;40:536-41.

9. Stenzl A, Ninkovic M, Willeit J, et al. Free neurovascular transfer of latissimus dorsi muscle to the bladder. I. Experimental studies. J Urol 1997;157:1103-8.

10. Ninkovic M, Stenzl A, Hess M, et al. Functional urinary bladder wall substitute using a free innervated latissimus dorsi muscle flap. Plast Reconstr Surg 1997;100:402-11.

11. Stenzl A, Ninkovic M, Kolle D, et al. Restoration of voluntary emptying of the bladder by transplantation of innervated free skeletal muscle. Lancet 1998;351:1483-5.

12. Ninkovic M, Stenzl A, Schwabegger A, et al. Free neurovas- cular transfer of latisstmus dorsi muscle for the treatment of bladder acontractility: II. clinical results. J Urol 2003;169: 1379-83.

13. Gakis G, Ninkovic M, van Koeveringe GA, et al. Functional detrusor myoplasty for bladder acontractility: long-term results. J Urol 2011;185:593-9.

14. Stenzl A, Ninkovic M. Restoring voluntary urinary voiding using a latissimus dorsi muscle free flap for bladder reconstruction. Microsurgery 2001;21:235-40.

15. Zhang YH, Shao QA, Wang JM. Enveloping the bladder with displacement of flap of the rectus abdominis muscle for the treatment of neurogenic bladder. J Urol 1990;144:1194-5.

16. Messing EM, Dibbell DG, Belzer FO. Bilateral rectus femoris pedicle flaps for detrusor augmentation in the prune belly syndrome. J Urol 1985;134:1202-5.

17. Ninkovic M, Dabernig W. Flap technology for reconstructions of urogenital organs. Curr Opin Urol 2003;13:483-8. 